Climate Change and Water Resources in the Sacramento-San Joaquin Region of California (W.E. Riebsame and J.W. Jacobs, 1988, 70 pp., \$4.50, paperbound, working paper \#64, Institute of Behavioral Science) This working paper belongs to a series that presents research in progress in the field of human adjustments to natural hazards. These papers are intended to be both working documents for the group of scholars directly involved in hazard research and information sources for the larger circle of interested people. This paper is a study of the SacramentoSan Joaquin region's particular vulnerability to the changes in precipitation and temperature that might result from the greenhouse effect. Besides water supply and flood control, two other water management issues in the area are especially sensitive to climate change: land use and levee maintenance in the Sacramento-San Joaquin Delta, and water quality in the delta. The authors assess the potential climate change effects and the range of possible responses for each.

Ecological Engineering: An Introduction to Ecotechnology (W.J. Mitsch and S.E. Jorgensen, eds., 1989, 472 pp., \$54.95, hardbound, John Wiley \& Sons). This book proposes a new approach to dealing with global warming, ozone depletion, dying lakes, ocean dumping, polluted mine drainage, garbage barges, polluted beach waste, and other problems while benefiting our natural ecosystem. The approach explored is one of cooperation between mankind and nature by using ecological modeling.

The book is divided into two parts. Part One consists of seven chapters introducing the basic definitions, concepts, and principles of ecological engineering. Part Two includes twelve chapters of case studies of ecological engineering from around the world. An index is included.

Northern Forest Border in Canada and Alaska (J.A. Larsen, 1989, 255 pp., \$79.50, hardbound, SpringerVerlag). The composition of plant communities of the ecotonal region between forest and tundra in central northern Canada are topics considered here. The purpose of this book is to delineate the habitat preferences of certain of the more common species. Contents include "Background and Setting," "Early Observations in the Northern Barrens," "The Forest/ Tundra Transition or Ecotone," "Physiography of Northern Study Areas," "Forest Border Community Structure," "Northern Soils," "Faunal Community
Relationships," "Essay on Diversity and Dominance," "Environment: Atmosphere," and "Summary and Conclusions." Eight Appendixes and a list of illustrations are included.

Satellite Remote Sensing: An Introduction (R. Harris, 1987, 220 pp., \$27.50, paperbound, Routledge \& Kegan Paul Ltd.). This book is designed to give students a sound basis and introduction to this fast changing field. The book covers undergraduate courses in remote sensing as part of a degree in an environmental science discipline such as geography, geology, agriculture, biology, oceanography, and meteorology.

The author examines the physical basis of remote sensing, the sensors and satellites used to collect data, and the methods used to process these data. He discusses applications of satellite remote sensing in the study of vegetation, land use, geology, soils, the atmosphere, and the hydrosphere. Examples are drawn from Britain, Europe, the United States, Canada, China, the USSR, the Middle East, Australia, and Africa. The book features imagery from METEOSAT, NOAA, LANDSAT, SEASAT, and SPOT satellite, and from NASA's Space Shuttle, and also incudes analyses based on a wide variety of American, European, and Japanese satellites. In his concluding chapter, the author looks at the way forward into the next decade and the next century.

\section{Publishers' Addresses}

Artech House, 685 Canton Street, Norwood, MA 02062

A. A. Balkema Publishers, P.O. Box 230, ACcord, MA 02018

Institute of Behavioral Science \#6, Natural Hazard Research Working Paper Series, Campus Box 482, University of Colorado, Boulder, CO 80309

Routledge \& Kegan Paul, Inc., 29 West 35th Street, New York, NY 10001

Springer-Verlag New York, Inc., 175 Fifth Avenue, New York, NY 10010

Taylor \& Francis, Inc., 242 Cherry Street, Philadelphia, PA 19106-1906

John Wiley \& Sons, Inc., 605 Third Avenue, New York, NY 10158 